\title{
The Triple Disaster as an Opportunity \\ to Feel Japanese Again in Hawaii
}

\section{Jutta Teuwsen}

\section{Introduction}

This paper will analyze the effect of the 3/11 Triple Disaster on the process of identity formation of Japanese Americans living in Hawaii. Of all Japanese diasporas, Hawaii's has a special significance because in relation to the overall population, its Japanese American population is larger than all other Japanese diasporas abroad. Historically, Hawaii was one of the first destinations to where large groups of Japanese workers migrated during the late nineteenth century.

During a fieldwork project focusing on the Japanese department store Shirokiya between August and November 2011, I realized that the construction of a specific Japanese identity in Hawaii was in a period of transition and that $3 / 11$ played an important part in this ongoing process. In interviews conducted with nisei and sansei, it became evident that not only their feelings of identity and their understanding of and dealing with their Japanese heritage was influenced by this overseas catastrophe, but also the social conditions for Japanese Americans in Hawaii have been changing since the disaster.

In order to understand what effect $3 / 11$ had on the status of the Japanese Americans in Hawaii and how these changes can be explained, this paper will give attention to five aspects. First, I will give a brief overview of the Japanese American population in Hawaii as it is today. Second, I will focus on the history of Japanese immigration to Hawaii, followed by an analysis of the social status of the Japanese American diaspora and then the reaction of the Hawaiian population on $3 / 11$. This paper ends with a short outlook on the future of Japanese Americans in Hawaii after 2011.

\section{Japanese American Hawaii}

According to the 2010 US census, nearly 23 percent of Hawaii's population claimed to be Japanese or Japanese in combination with at least one other race. 
Of these, more than 185,000 - almost two-thirds - claimed to be only Japanese, which is 13.69 percent of Hawaii's total population. It is striking that even after five generations, gose ${ }^{1}$ still claim to be Japanese. Even now, the majority of nisei does not speak Japanese fluently, perhaps because their parents' generation, the issei, had to endure growing nationalistic sentiments in the US after World War I, and as a result learned to adjust to the English language (Kimura 1988: 185). Therefore, even if their parents were native Japanese speakers, subsequent generations spoke Pidgin English, which evolved as a major language on the plantations where the majority of Japanese immigrant laborers worked. For the nisei generation, it meant that they grew up in an English-language environment; thus, English became their first language. If these second generation Japanese studied Japanese at all, they learned it as a second language in Japanese language schools. However, after the Japanese attack on Pearl Harbor on December 7, 1941, the Japanese language schools closed down and the public use of Japanese language was even prohibited because, in a socio-political context, Americans of Japanese descent were suspected to be secretly working for their mother country (Kimura 1988: 225; Odo 2003: 101-116). Only in 1947 did some of the Japanese language schools reopen, but by then the nisei generation had hardly spoken Japanese for many years (Kimura 1988: 254). Thus, while the majority of the nisei might have or have had only basic knowledge of the Japanese language, the following generations generally do not speak or understand Japanese.

The situation for the Japanese Americans in Hawaii, therefore, differs significantly from the typical transient Japanese experience elsewhere in the world. Many Japanese live only temporarily in London, Brussels, Dusseldorf and Paris. They are dispatched by their companies and accompanied by their families but will return to Japan after a few years abroad. In contrast, people of Japanese origin in North and South America and in Hawaii can often trace the moment of their families' immigration back four or five generations. Accordingly, they see themselves as Americans with a Japanese background. Many are born in the US with English as their native language. Japan is certainly a popular destination for

1 Gosei are fifth-generation Japanese. 
tourists and a place that is somehow connected to nostalgic feelings for Hawaiian Japanese Americans, but they still consider their homeland to be Hawaii - that is, the US. However, there is also a minority that rather fits to the description of a transient diasporic community. This group consists of individuals coming to Hawaii for a certain period of time, going back to Japan after one or two years. In general they are surfing teachers or occupy other jobs related to Hawaii's tourist industry that significantly depends on Japanese tourists. However, the majority of individuals with Japanese background are descendants of the Japanese immigrants from around 1900.

\section{History of Japanese Immigration to Hawaii}

In 1868, year one of the Meiji-period, the first group of 148 Japanese men went to Hawaii to work on the sugar plantations. These Gannen-mono (Meiji first-year people) mark the beginning of Japanese diaspora (Befu 2001: 3-22; Danniels 2006: 31). The Japanese workers came to Hawaii on a three-year contract. Initially, all migrant workers intended to return home after having earned sufficient money. They had the plan to take the money back home to Japan and have a better life with their families (Befu 2010: 34). However, due to bad working conditions, some of the workers went home even before their contracts ended, and only 90 gannen-mono decided to settle down in Hawaii (Kimura 1988: 3). After successful negotiations regarding changes to working conditions and the improvement of contracts, Japanese immigration increased and more migrant workers settled down in Hawaii and stayed for good. By 1898, more than 16,000 Japanese were living in Hawaii (Kimura 1988: 13). In the same year, Hawaii became a territory of the US, this had significant effects on the Japanese immigrants to Hawaii. As one consequence, Japanese no longer had to find contracts with sugar plantations in order to be allowed to migrate to Hawaii. Between 1900 and 1907, more than 68,000 Japanese went to Hawaii; not all of them stayed, and more than 35,000 Japanese left for the west coast of the US, drawn by the expectation of higher wages (Kimura 1988: 13-15). Due to the high numbers of Japanese immigrants, an informal "Gentlemen's Agreement" was arranged between the US and Japan in 1907/08 (Sawada 1991: 339-359). From that time 
forward, Japan restricted passports, issuing them only to close kin and "picture brides" of those Japanese already living in the US. ${ }^{2}$ Finally, in 1924, a clause of the US Immigration Act completely barred Japanese immigration and led to strong tensions between the Japanese government and the US and also sparked weak movement albeit Japanese Americans aimed for the revision of the Act (Hirobe 2002). In that year, 125,368 Japanese were living in Hawaii. After immigration was legalized again, Hawaii returned to its status as a popular destination for Japanese immigrants. Even today, the Japanese American population remains one of the largest "racial" groups in Hawaii according to the 2010 census (US Census Bureau 2010).

\section{The Social Status of Japanese Americans in Hawaii}

The outlined historical circumstances indicate why we cannot compare the Japanese American diaspora of Hawaii with transient diasporas in Europe. The Japanese are an integral part of the overall population of Hawaii and see themselves as locals. The term "local" is to some extent opposed to what is generally understood as "diaspora": "local" represents the shared identity of all Hawaiian people who have an appreciation and commitment to the islands, people and way of life. Being local in Hawaii is inclusive - local people can be of Japanese, Chinese, Portuguese or any other ancestry. They are local first and foremost. Finally, being local is not about one's heritage but about presence; it is about living in Hawaii right now, which suggests that Hawaii’s Japanese Americans deal with their history of immigration in a different way compared to other Japanese diasporic communities. However, there are also historical reasons why this group does not publicly demonstrate its Japanese background. Over time, the image of the Japanese American population changed continuously.

In 1909 and 1920, the Japanese on the sugar plantations went on strike for better working conditions. The Filipino Labor Union initiated the second strike in 1920 (Duus 1999). However, the Japanese workers joined belatedly, and union

2 Picture brides were Japanese women sent from Japan to Hawaii in order to enter into an arranged marriage. The practice got started when the immigrants realized that they could not accumulate enough money to go back to Japan soon trough their work (Yun Chai 1988). The future husbands had nothing but a picture, waiting for the brides to arrive at the harbor. 
leaders on both sides mistrusted each other and diverged on the general aims of the strike (Pierce 2007: 577). These strikes were only partly successful and lead to a deep resentment towards the Japanese by groups of workers. As a result, many Japanese left the cane fields. The number of Japanese who worked on the fields declined only from 1930 onwards, and those who remained increasingly occupied minor positions of responsibility, like field overseers (Kimura 1988: 10of.). As a result, both working and living conditions improved noticeably, and the nisei born around 1930 did not experience the constraints of the earlier years.

While the conditions on the cane fields improved and increasing numbers of issei advanced to positions with more responsibility, a solid base for the following Japanese American generation was built: major institutions and organizations had been established and took root, like the United Japanese Society in 1932, and Japanese vernacular newspapers were widely spread (Kimura 1988: 178f.) The political, economic and social influence of the Japanese American population in Hawaii grew and more and more parents could afford to send their children to colleges on the US mainland. The results are still visible today - as a group, Japanese Americans are socioeconomically very successful (Okamura 2008: 127).

Japanese Americans in Hawaii occupy influential administrative, professional and clerical occupations on all state levels and are highly visible. However, from the 1970 on onwards, this visibility gradually evolved into a negative stereotype and the Japanese American communities were resented because of their success. Furthermore, the Japanese became the scapegoats for social and economic problems. As a consequence, this group refrained from stressing their Japanese identity and instead focused on their local identity.

Because the Japanese American community tended to hold back their ethnic background, it is promising to analyze the groups' reaction following the triple disaster. During my field research in Hawaii, I interviewed a number of Japanese Americans, especially those with ties to the prefecture of Fukushima and also approached the Japanese Cultural Center of Hawaii and the Ethnic Studies Department of the University of Hawaii. The impression I got from my interviews seemed to be in line with the opinions of the experts: The "public denial" 
of a Japanese heritage did neither result in a much less visible reaction by the Japanese communities towards $3 / 11$ compared to other diasporic communities nor in a highly visible reaction. Their reaction did not differ from other Japanese American groups in Hawaii. And they did not play a key role in promoting the visibility of the Japanese American communities after 3/11. To sum it up, the reaction towards $3 / 11$ was intense through all social strata and local communities in Hawaii and unrelated to ethnic background or geographical descent in Japan.

\section{Reactions On 3/11}

Following the 3/11 catastrophe, there have been beneficial events and donations as well as other activities. Furthermore, the overall presence of the incident as well as the presence of Japanese Americans - in the media has been striking. It is remarkable to what extent the triple disaster dominates the economical and political sections in Hawaii's local newspapers from 2011. In that respect, Hawaii is probably not different from other places because people all over the world showed their interest and compassion for Japan and the Japanese. However, the triple catastrophe also dominated local news. The Japanese Cultural Center of Hawaii initiated many benefit events, and the Japan-America Society of Hawaii started a great part of the fund raising. Likewise, local organizations were and are still engaged in aiding Japan. The Aloha for Japan initiative involves more than 160 Hawaiian financial institutions, merchants, schools and community groups. Because Hawaii depends significantly on Japanese tourism, companies like Hawaiian Airlines and major hotel groups also felt the need to show their support through financial donations for aid and reconstruction.

Many Hawaiians participated in events and donated individually. One example of an event is the Lei Day for Japan. A lei is a Hawaiian necklace made of flowers. Respected individuals and guests are honored by receiving a lei, which is a crucial element in many festivities. The lei is strongly connected to the concept of friendship and is supposed to foster feelings of belonging. Since 1928, Lei Day has been a national holiday, and Steven J. Friesen has pointed out how the lei as well as Lei Days have contributed to the construction of an ethnic identity on the Hawaiian islands (Friesen 1996: 1-36). This festival is celebrated on May 
1, and in 2011 it was turned into the Lei Day for Japan by Hawaian Airlines. The airline organized a music and cuisine benefit event held at the very prominent Aloha Tower Marketplace in Honolulu; the benefit raised more than $\$ 200,000$.

Finally, the numbers provided by the American Red Cross Hawaii State Chapter are most telling: The people of Hawaii, with a population of not more than about 1.3 million people, raised over six million dollars to aid the Japan relief effort. Many schools, NGOs, companies and individuals made donations ranging from $\$ 1$ to $\$ 50,000$. Examples of fund-raising activities include car washes, bake sales and a telethon with a concert held on the lawn of the Hilton Hawaiian Village; here performers donated their time and talent while people from around the world watched on television and/or via computers and made donations to the Red Cross online as well as by phone. A group of companies and banks worked together with the Hawaiian Red Cross and Japan American Society of Hawaii to coordinate efforts on all islands.

I would like to stress that the Hawaiian population donated significantly higher amounts of money to the victims of 3/11 than they had ever donated before for other catastrophes like Hurricane Katrina or 9/11. During the first two weeks after the earthquake, the American Red Cross Hawaii State Chapter received more than $\$ 640$,000 from Hawaiian residents, which was more than triple the $\$ 190,000$ sum that was donated two weeks after the Haiti earthquake.

The generosity of the Hawaiian population can be traced back to four reasons. The first reason is that both islands, Hawaii and Japan, were threatened by the same tsunami. It hit Japan worst, but the Hawaiian people are highly aware of the fact that it could have happened to them. This feeling was intensified by a historical precedence: in 1960, a massive earthquake close to the coast of Chile (magnitude 9.5), which was actually the strongest recorded earthquake in the twentieth century, led to a tsunami that traveled around half the globe. It first hit Hawaii, after crossing 10,000 km of the Pacific, and killed 61 people. However, the tsunami did not stop in Hawaii and reached the coast of Tōhoku, the site of the triple catastrophe in 2011, eight hours later. Government officials as well as the general population in Japan did not expect that the tsunami would still be powerful enough to cause damage when reaching the shore and were thus unpre- 
pared. Although the news had broadcast that Hawaii had been hit by a tsunami, no official warning was released for the Eastern Coast of Japan (Yoshimura 2004: 156). When the tsunami finally reached Japanese shores, it killed another 161 people.

Thus, Hawaiian people in 2011 took a highly empathetic position because they could easily imagine that they could have experienced a similar scenario. Nevertheless, the tsunami of 2011 caused $\$ 22$ million in property damage in Hawaii and forced the closure of two hotels. For Japanese Americans, being reminded of the Great Hanshin earthquake of 1995 might even have led to a flashback experience because they felt personally involved through their Japanese heritage, and as a result, they reacted with even more empathy.

The second, and probably more influential reason for the high amount of donations given by the Hawaiian people is that the Japanese Americans constitute such a high percentage of the overall population, which means that they are present and influence or affect all socio-economic spheres. This presence of the Japanese Americans, although they refrained from publicly showcasing their Japanese American identity, is still highly visible all over the island. There are Japanese restaurants, and green tea drinks and matcha ice cream (green tea ice cream) are available throughout the islands. The major Japanese department store Shirokiya defends a very prominent spot at the country's biggest shopping center: the Ala Moana Center in Honolulu. It was to be closed several times, but different interest groups are still fighting to keep it open. The crucial aspect is that things "Japanese" are considered to be a significant characteristic of Hawaii for all local people - independent from their ethnic background. Even if the perception of the Japanese Americans might be judged positively or negatively, they are in fact a part of the locals' everyday life. Thus, 3/11 affected not only the Japanese American communities but also each and every individual claiming to be local.

Third, the constant and visible presence of tourists from Japan also ought to be seen as a significant reason for the contributions of local communities. Most of the local communities are aware of the fact that Japanese tourism is one of the major pillars of the prosperous local economy. Of all tourists, 17.3 percent 
who came by air in 2011 came from Japan. Nearly two million Japanese fly to Hawaii every year. Japanese tourists spend the most per day, averaging $\$ 289$ whereas the average amount of money spent per day by tourists is only $\$ 179$. Contributions to the relief efforts are therefore important to reciprocate the Japanese tourists' generosity. Furthermore, the donations make sure that the positive image Japan has of Hawaii will remain at the same high level and uphold a continuous stream of Japanese tourism to Hawaii. It is certainly not by accident that Hawaiian Airlines was keen to organize the Lei Day for Japan.

Finally, the high amount of individual funding can be traced back to the long tradition of gift giving and reciprocity of local groups in Hawaii. Colleen Leahy Johnson analyzes the reasons for this practice in the case of Japanese Americans in Honolulu (Johnson 1974: 295-308). She claims that gift giving aims at keeping a balanced reciprocity, serving all essential social functions. In detail, she differentiates four means of gift giving to support and promote social functions: "facilitating status placement, providing general continuities, reducing conflict, and equalizing class difference" (Johnson 1974: 295). The reciprocity of individual funding after $3 / 11$ might point to an acknowledgement of what Japanese Hawaiians and tourists have done for Hawaii. Donors certainly could not have expected direct reciprocal returns for their support after $3 / 11$.

\section{The Future of Japanese Americans in Hawaii after 2011}

As argued earlier, the status of the Japanese American community has changed during the last decades. Japanese Americans did not promote their ethnic identity actively because they were resented due to their success. They were used to being made responsible for social and economic problems, but conditions have significantly changed since the $3 / 11$ catastrophe. The negative perceptions of the Japanese American communities by other locals appeared to be obsolete because the triple disaster was the first thing that came on the locals' mind in the context of Japan or anything Japanese. A complex construct of prejudice, experience and shared history with the Japanese Americans had evolved over more than one decade, but it seems that it was reset in one day. After decades of holding back their Japanese heritage, 3/11 allowed Japanese Americans to show their heritage 
freely and openly again. Apart from their local immersion, now they are again placed in the context of the homeland of their acclaimed ancestors.

To conclude, 3/11 has brought about significant changes in the self-image as well as in the perception of the Japanese American communities of Hawaii. It will be interesting to see how this new setting will influence the future image and self-image of the Japanese American groups. As time goes by, former and well-known structures of behavior and perception might find their way back; nevertheless, there is a chance that the new setting might persist.

\section{Literature}

American Anthropological Association. 1997. "Race and Ethnic Standards for Federal Statistics and Administrative Reporting”. Response to OMB Directive 15. http://www.aaanet.org/gvt/ombsumm.htm. (accessed 3January 30, 2012)

Befu, Harumi. 2001. “The Global Context of Japan Outside Japan.” In: Befu, Harumi; Guichard-Anguis, Sylvie (eds.): Globalizing Japan: Ethnography of the Japanese Presence in Asia, Europe and America. London: Routledge, pp. 3-22.

Befu, Harumi. 2010. "Japanese Transnational Migration in Time and Space: A Historical Overview." In: Adachi, Nobuko (ed.): Japanese and Nikkei at Home and Abroad. Negotiating Identities in a Global World. New York: Cambria, pp. 31-49.

DANIEls, Roger. 2006. "The Japanese Diaspora in the New World: Its Asian Predecessors and Origins." In: Adachi, Nobuko (ed.): Japanese Diasporas: Unsung Pasts, Conflicting Presents, and Uncertain Futures. London: Routledge, pp. 25-34.

Duus, Masayo. 1999. The Japanese Conspiracy: The Oahu Sugar Strike of 1920. Oakland, CA: U of California P.

Friesen, Steven J. 1996. “The Origins of Lei Day: Festivity and the Construction of Ethnicity in the Territory of Hawaii." History and Anthropology. 10 (1): pp. 1-36.

Hirobe, Izumi. 2002. Japanese Pride, American Prejudice: Modifying the Exclusion Clause of the 1924 Immigration Act. Stanford: Stanford UP.

Johnson, Colleen Leahy. 1974. "Gift Giving and Reciprocity Among the Japanese Americans in Honolulu." American Ethnologist. 1 (2): pp. 295-308.

Kimura, Yukiko. 1988. Issei. Japanese Immigrants in Hawaii. Honolulu: U of Hawaii P.

Odo, Franklin S. 2003. No Sword to Bury: Japanese Americans in Hawai'i During World War II. Philadelphia: Temple UP.

Oкамura, Jonathan Y. 2008. Ethnicity and Inequality in Hawai'i. Philadelphia: Temple University Press. 
The Triple Disaster as an Opportunity to Feel Japanese Again in Hawaii

Pierce, Lori. 2007. "Hawaii Laborers' Association.” In: Arnesen, Eric (ed.) Encyclopedia of U.S. Labor and Working-Class History. New York: Routledge, pp. 576-577.

SawAdA, Mitziko. 1991. "Culprits and Gentlemen: Meiji Japan's Restrictions of Emigrants to the United States, 1891-1909." In: Pacific Historical Review. 60 (3): pp. 339-359.

U.S. Census Bureau. 2010. http://www.uscensus2010data.com/. (accessed January 29, 2012)

Yoshimura, Akira. 2004. Sanriku kaigan òtsunami [Great Tsunamis on the Coast of Sanriku]. Tokyo: Bungei shunjū.

Yun Chai, Alice. 1988. "Women's History in Public: 'Picture Brides' of Hawaii." In: Women's Studies Quarterly. 16 (1/2): pp. 51-62. 
